\title{
Analisis Mutu Pelayanan Terhadap Tingkat Kepuasan Pasien di Laboratorium Rumah Sakit Umum Daerah Kota Mataram
}

\author{
Tri Teguh Santoso, Zainal Fikri, Yudha Anggit Jiwantoro
}

Jurusan Analis Kesehatan, Poltekkes Kemenkes Mataram, Indonesia

\begin{tabular}{l} 
Article Info \\
Article history: \\
Received Feb $19^{\text {th }}, 2021$ \\
Revised Feb $24^{\text {th }}, 2021$ \\
Accepted Mar $09^{\text {th }}, 2021$ \\
\hline
\end{tabular}

Keyword:

Quality of service,

level of patient

satisfaction,

health laboratory

services

\begin{abstract}
The hospital is a form of health facility, both organized by the government and the community that functions to conduct basic health efforts or referral health by improving the quality of services. The quality of health services is an important factor in the success of a hospital, where there are laboratory services that cannot be separated from the hospital. The services provided by the laboratory are very influential on the level of patient satisfaction. How to measure the level of patient satisfaction using five dimensions of service quality, tangible, reliabilty, responsiveness, assurance and empathy. Knowing quality of service to the level of patient satisfaction in hospital laboratories Mataram. This type of research is an analytic survey with cross sectional design. The population in this study were laboratory patients in Mataram City Hospital, as many as 98 research samples. Purposive sampling technique with sample criteria. Data collection using a questionnaire about the effect of service quality on the level of patient satisfaction. Data analysis with chi square test. The results of the research characteristics of respondents based on five dimensions of service quality, obtained results of service quality variables: tangible good (67.4\%), not good (32.6\%), good reliability (83.7\%), not good (16.3\%), responsiveness is good (94.0\%), not good (6.0\%), assurance is good (51.1\%), not good (48.9\%), and empathy is good (97.0\%), not good (3.0\%). The patient satisfaction variable of respondents who said they were satisfied was (74.5\%). The results showed that $p$ value (0.000). There is an influence of service quality on the level of patient satisfaction in the laboratory of Mataram City Hospital.
\end{abstract}

\begin{abstract}
ABSTRAK
Rumah sakit merupakan salah satu bentuk sarana kesehatan, baik yang diselenggarakan oleh pemerintah maupun masyarakat yang berfungsi untuk melakukan upaya kesehatan dasar atau kesehatan rujukan dengan meningkatkan mutu pelayanan. Mutu pelayanan kesehatan merupakan faktor penting dalam keberhasilan suatu rumah sakit, dimana terdapat pelayanan laboratorium yang tidak dapat terpisahkan dengan rumah sakit. Pelayanan yang diberikan laboratorium sangat berpengaruh terhadap tingkat kepuasan pasien. Cara pengukuran tingkat kepuasan pasien menggunakan lima dimensi mutu pelayanan seperti, bukti fisik (tangible), kehandalan (reliabilty), ketanggapan (responsiveness), jaminan (assurance), dan empati (empathy). Mengetahui mutu pelayanan terhadap tingkat kepuasan pasien di laboratorium RSUD Kota Mataram. Jenis penelitian ini adalah survei analitik dengan rancangan cross sectional. Populasi dalam penelitian ini adalah pasien laboratorium RSUD Kota Mataram, sampel penelitian sebanyak 98 orang. Tekknik pengambilan sampel purposive sampling dengan kriteria sampel. Pengumpulan data menggunakan kuesioner tentang pengaruh mutu pelayanan terhadap tingkat kepuasan pasien. Analisis data dengan uji chi square. Hasil penelitian karakteristik responden berdasarkan lima dimensi mutu pelayanan, didapatkan hasil variabel mutu pelayanan: tangible baik $(67,4 \%)$, tidak baik $(32,6 \%)$, reliability baik $(83,7 \%)$, tidak baik $(16,3 \%)$, responsiveness baik $(94,0 \%)$, tidak baik $(6,0 \%)$, assurance baik $(51,1 \%)$, tidak baik $(48,9 \%)$, dan empathy baik $(97,0 \%)$, tidak baik $(3,0 \%)$. Variabel kepuasan pasien responden yang mengatakan puas sebesar (74,5\%). Hasil penelitian menunjukkan $\mathrm{p}$ value (0.000). Ada pengaruh mutu pelayanan terhadap tingkat kepuasan pasien di laboratorium RSUD Kota Mataram.
\end{abstract}

Kata Kunci : Mutu pelayanan, tingkat kepuasan pasien, pelayanan laboratorium kesehatan. 


\section{Pendahuluan}

Pembangunan dibidang kesehatan di Indonesia bertujuan untuk mencapai masyarakat yang memiliki kemampuan untuk mewujudkan keadaan yang sehat baik secara jasmani maupun rohani. Berdasarkan hal ini pemerintah telah berupaya dalam membangun pelayanan kesehatan yang mudah dijangkau oleh semua lapisan masyarakat tanpa membedakan status sosial ekonomi seseorang dalam memperoleh pelayanan kesehatan yang adil dan merata. Salah satu tempat pelayanan kesehatan adalah rumah sakit (Margono \& Wardani, 2018).

Rumah sakit merupakan salah satu bentuk sarana kesehatan, baik yang diselenggarakan oleh pemerintah maupun masyarakat yang berfungsi untuk melakukan upaya kesehatan dasar atau kesehatan rujukan. Mutu pelayanan kesehatan di rumah sakit adalah produk akhir dari interaksi dan ketergantungan yang rumit antara berbagai aspek dalam upaya meningkatkan suatu pelayanan yang baik. Salah satu pelayanan penunjang di rumah sakit adalah laboratorium. Pelayanan laboratorium rumah sakit merupakan salah satu kegiatan dirumah sakit yang menunjang pelayanan kesehatan bermutu (Mardiana \& Rahayu, 2017).

Sarana dan fasilitas di laboratorium rumah sakit akan memberikan dampak terhadap kualitas pelayanan terhadap masyarakat, sarana yang memadai, akses yang mudah serta fasilitas yang lengkap akan memberikan pengaruh terhadap kepuasan pasien/pelanggan pengguna jasa layanan kesehatan. Kepuasan pasien dapat di analisa berdasarkan dimensi mutu pelayanan kesehatan (Handiwidjojo, 2014).

Dimensi mutu pelayanan kesehatan merupakan suatu jaminan untuk menentukan atau mengetahui kualitas pelayanan. Adapun lima dimensi mutu pelayanan kesehatan, seperti tangible (bukti fisik) dapat berupa ketersediaan sarana dan prasarana serta penampilan karyawan, reliability (kehandalan) dapat berupa kemampuan dalam memberikan pelayanan yang baik, responsiveness (ketanggapan) berupa keinginan karyawan membantu konsumen serta tanggap dalam melayani, assurance (jaminan) dapat berupa kesopanan dan dapat dipercaya dari karyawan, empathy (empati) berupa karyawan dapat berkomunikasi dengan baik terhadap konsumen (Nafs et al., 2017). Tujuan dari penelitian ini adalah untuk mengetahui mutu pelayanan terhadap tingkat kepuasan pasien di laboratirum Rumah Sakit Umum Daerah Kota Mataram.

\section{Metode Penelitian}

Jenis penelitian ini adalah survei analitik yang dilakukan diruang tunggu laboratorium yang bertujuan untuk menggali bagaimana dan mengapa fenomena kesehatan itu terjadi. Kemudian melakukan analisis dinamika korelasi antara fenomena, baik faktor resiko dengan faktor efek (Notoatmodjo, 2014). Sedangkan rancangan penelitian yang digunakan bersifat cross sectional yaitu peneliti melakukan pengamatan langsung kepada responden dan pengambilan sampel untuk variabel bebas dan terikat dilakukan sekaligus pada waktu yang sama .

Pengukuran tingkat kepuasan pasien berdasarkan nilai median. Pasien dikatakan baik atau puas apabila nilai dari data yang didapatkan $\geq$ nilai median. Sedangkan dikatakan tidak baik atau tidak puas apabila nilai dari data yang didapatkan $\leq$ nilai median. Analisis data yang digunakan adalah chi square (crosstabs) untuk mengetahui apakah ada hubungan antara kedua variabel tersebut (Metode Penelitian Kuantitatif \& Kualitatif, 2010).

Hasil Penelitian dan Pembahasan

Tabel 1. Distribusi Frekuensi Dimensi Tangible (Bukti Fisik)

\begin{tabular}{|c|c|c|c|}
\hline \multirow{2}{*}{ No } & \multirow{2}{*}{ Kategori } & \multicolumn{2}{|c|}{ Jumlah } \\
\cline { 3 - 4 } & & Frekuensi & Persentase \\
\hline 1 & Baik & 66 & $67,4 \%$ \\
2 & Tidak Baik & 32 & $32,6 \%$ \\
\hline & Jumlah & 98 & $100 \%$ \\
\hline
\end{tabular}

Berdasarkan tabel diatas, responden yang mengatakan baik pada dimensi tangible (bukti fisik) adalah 67,4\% (66 orang).

Tabel 2. Distribusi Frekuensi Dimensi Reliability (Kehandalan)

\begin{tabular}{|c|c|c|c|}
\hline \multirow{2}{*}{ No } & \multirow{2}{*}{ Kategori } & \multicolumn{2}{|c|}{ Jumlah } \\
\cline { 3 - 4 } & & Frekuensi & Persentase \\
\hline 1 & Baik & 82 & $83,7 \%$ \\
2 & Tidak Baik & 16 & $16,3 \%$ \\
\hline & Jumlah & 98 & $100 \%$ \\
\hline
\end{tabular}

Berdasarkan tabel diatas, responden yang mengatakan baik pada dimensi reliability (kehandalan) adalah $83,7 \%$ (82 orang).

Tabel 3. Distribusi Frekuensi Dimensi Responsiveness (Ketanggapan)

\begin{tabular}{|c|c|c|c|}
\hline \multirow{2}{*}{ No } & \multirow{2}{*}{ Kategori } & \multicolumn{2}{|c|}{ Jumlah } \\
\cline { 3 - 4 } & & Frekuensi & Persentase \\
\hline 1 & Baik & 92 & $94,0 \%$ \\
2 & Tidak Baik & 6 & $6,0 \%$ \\
\hline & Jumlah & 98 & $100 \%$ \\
\hline
\end{tabular}

Berdasarkan tabel diatas, responden yang mengatakan baik pada dimensi responsiveness (ketanggapan) adalah 94,0\%

(92 orang). 


\section{Tabel 4. Distribusi Frekuensi Dimensi Assurance (Jaminan)}

\begin{tabular}{|c|c|c|c|}
\hline \multirow{2}{*}{ No } & \multirow{2}{*}{ Kategori } & \multicolumn{2}{|c|}{ Jumlah } \\
\cline { 3 - 4 } & & Frekuensi & Persentase \\
\hline 1 & Baik & 50 & $51,1 \%$ \\
2 & Tidak Baik & 48 & $48,9 \%$ \\
\hline & Jumlah & 98 & $100 \%$ \\
\hline
\end{tabular}

Berdasarkan tabel diatas, responden yang mengatakan baik pada dimensi assurance (jaminan) adalah 51,1\% (50 orang).

\section{Tabel 5. Distribusi Frekuensi Dimensi Empathy (Empati)}

\begin{tabular}{|c|c|c|c|}
\hline \multirow{2}{*}{ No } & \multirow{2}{*}{ Kategori } & \multicolumn{2}{|c|}{ Jumlah } \\
\cline { 3 - 4 } & & Frekuensi & Persentase \\
\hline 1 & Baik & 95 & $97,0 \%$ \\
2 & Tidak Baik & 3 & $3,0 \%$ \\
\hline & Jumlah & 98 & $100 \%$ \\
\hline
\end{tabular}

Tabel 6. Hasil Uji Statistik

\begin{tabular}{|l|c|c|}
\hline \multicolumn{1}{|c|}{ Dimensi } & $\mathbf{P}$ & Kesimpulan \\
\hline Tangible & 0,000 & Ada Hubungan \\
\hline Reliability & 0,000 & Ada Hubungan \\
\hline Responsiveness & 0,000 & Ada Hubungan \\
\hline Assurance & 0,000 & Ada Hubungan \\
\hline Empathy & 0,000 & Ada Hubungan \\
\hline
\end{tabular}

Hubungan mutu pelayanan dengan tingkat kepuasan pasien berdasarkan tabel diatas, dapat dikatakan bahwa ke lima dimensi mutu pelayanan tersebut berpengaruh secara simultan atau bersamaan terhadap tingkat kepuasan pasien di laboratorium Rumah Sakit Umum Daerah Kota Mataram.

Hasil dari uji chi square atau kai kuadrat antara ke lima dimensi mutu pelayanan terhadap kepuasan pasien menunjukkan adanya hubungan antara variabel bebas yakni, dari lima dimensi mutu pelayanan (tangible, reliability, responsiveness, assurance, dan empathy) terhadap variabel terikat yakni kepuasan pasien, karena masing-masing variabel mutu pelayanan terhadap variabel kepuasan pasien memiliki nilai probabilitas 0,000 yang artinya kurang dari 0,01. Dikatakan ada hubungan berdasarkan pengambilan keputusan, dari uji chi square masing-masing variabel mutu pelayanan terhadap variabel kepuasan pasien apabila probabilitas $>0,01$ maka $\mathrm{H}_{0}$ diterima yang artinya tidak ada hubungan antara kedua variabel tersebut, tetapi jika probabilitas $<0,01$ maka $\mathrm{H}_{0}$ ditolak yang artinya ada hubungan antara kedua variabel tersebut.

Sebagaimana dikatakan oleh (Azwar, 2013) kualitas memiliki hubungan yang sangat erat dengan kepuasan pelanggan, yaitu kualitas memberikan suatu dorongan kepada pelanggan untuk menjalani ikatan hubungan yang kuat. Dikatakan juga oleh (Azwar, 2013) bahwa kualitas pelayanan merupakan pelayanan yang menunjukkan pada tingkat kesempurnaan, yang disatu pihak dapat menimbulkan kepuasan pada setiap pasien sesuai dengan tingkat kepuasan ratarata.

\section{Kesimpulan}

Berdasarkan analisis uji chi square atau kai kuadrat variabel mutu pelayanan (tangible, reliability, responsiveness, assurance, empathy) secara simultan (bersama-sama) berpengaruh signifikan terhadap variabel kepuasan pasien di laboratorium RSUD Kota Mataram. Hal ini dapat dilihat dari nilai signifikansi masing-masing variabel mutu pelayanan terhadap variabel kepuasan pasien dengan nilai signifikansi sebesar $0,000<0,01$. 


\section{Daftar Pustaka}

Azwar, S. (2013). Sikap Manusia: Teori dan Pengukurannya. In Sikap Manusia: Teori dan Pengukurannya. https://doi.org/10.1038/cddis.2011.1

Handiwidjojo, W. (2014). Sistem Informasi Manajemen Rumah Sakit. Jurnal EKSIS.

Mardiana, \& Rahayu, I. G. (2017). Pengantar Laboratorium Medik. In Bahan Ajar Teknologi Laboratorium Medis $(T L M)$.

Margono, H., \& Wardani, M. K. (2018). KEPUASAN PASIEN TERHADAP PELAYANAN RUMAH SAKIT. Jurnal Manajemen Kewirausahaan. https://doi.org/10.33370/jmk.v15i1.190

Nafs, T., Prodi, A.-Z., Psikologi, S., \& Psikologi, F. (2017). PENGARUH MUTU PELAYANAN KESEHATAN TERHADAP TINGKAT KEPUASAN PASIEN RAWAT INAP DI RUANG DEWASA UMUM RUMAH SAKIT X KABUPATEN GRESIK. PSIKOSAINS.

Notoatmodjo, S. (2014). Metodologi Penelitian Kesehatan (2nd ed.). Rineka Cipta.

Metode Penelitian Kuantitatif \& kualitatif, Journal of Experimental Psychology: General (2010). 